УДК 336.7

Ільчук Павло,

доктор економічних наук, професор, Національний університет «Львівська політехніка», кафедра технологій управління,

м. Львів, ORCID ID: 0000-0003-4636-2309, e-mail: pavlo.g.ilchuk@lpnu.ua

Коць Ольга, кандидат економічних наук, доцент, Національний університет «Львівська політехніка», кафедра фінансів, м. Львів, ORCID ID: 0000-0001-7123-3635, e-mail: olha.o.kots@lpnu.ua

Кудь Анастасія, Національний університет «Львівська політехніка», кафедра фінансів, м. Львів, ORCID ID: 0000-0001-5424-0972, e-mail: kudnasta3@gmail.com

https://doi.org/10.29038/2411-4014-2020-01-195-205

\title{
ПОКАЗНИКИ КАПІТАЛІЗАЦІЇ БАНКІВСЬКОЇ СИСТЕМИ УКРАЇНИ: ФАКТИЧНИЙ СТАН ТА ПОРІВНЯЛЬНА ХАРАКТЕРИСТИКА ІЗ ПОКАЗНИКАМИ ПОЛЬЩІ, ШВЕЙЦАРІЇ ТА НІМЕЧЧИНИ
}

У статті основну увагу зосереджено на аналізуванні капіталізації банківської системи України. Недостатній рівень капіталізації банківської системи України є проблемою впродовж усіх років незалежності. Визначення рівня капіталізації банківської системи України виконано на основі розрахунку та аналізування такого показника як частка капіталу у ВВП. Окремо було проаналізовано структуру капіталу банків. Порівняння капіталізації банківських систем України, Польщі, Швейцарії та Німеччини виконано на основі аналізування динаміки капіталу, активів та зобов'язань, окремих відносних показників (структури капіталу та ефективності його використання), а також коефіцієнта капіталізації. Виконане порівняння дає змогу використовувати найбільш відповідні українським реаліям практики управління капіталізацією банківською системою.

Ключові слова: банк, капітал, капіталізація, банківська система, оцінювання, порівняння.

Ильчук Павел, доктор экономическихн наук, профессор, Национальный университет «Львовская политехника», кафедра технологий управления, г. Львов

Коць Ольга, кандидат экономических наук, доцент, Национальный университет «Львовская политехника», кафедра технологий управления, г. Львов

Кудь Анастасия, Национальный университет «Львовская политехника», кафедра технологий управления, г. Львов 


\section{ПОКАЗАТЕЛИ КАПИТАЛИЗАЦИИ БАНКОВСКОЙ СИСТЕМЫ УКРАИНЫ: ФАКТИЧЕСКОЕ СОСТОЯНИЕ И СРАВНИТЕЛЬНАЯ ХАРАКТЕРИСТИКА С ПОКАЗАТЕЛЯМИ ПОЛЬШИ, ШВЕЙЦАРИИ И ГЕРМАНИИ}

В статье основное внимание сосредоточено на анализе капитализации банковской системы Украины. Недостаточный уровень капитализации банковской системы Украины является проблемой на протяжении всех лет независимости. Определение уровня капитализации банковской системы Украины выполнено на основе расчета и анализа такого показателя как доля капитала в ВВП. Отдельно были проанализирована структура капитала банков. Сравнение капитализации банковских систем Украины, Польши, Швейцарии и Германии выполнено на основе анализа динамики капитала, активов и обязательств, отдельных относительных показателей (структуры капитала и эффективности его использования), а также коэффициента капитализации. Выполненное сравнение дает возможность использовать наиболее подходящие украинским реалиям практики управления капитализацией банковской системы.

Ключевые слова: банк, капитал, капитализация, банковская система, оценки, сравнения.

Pavlo Ilchuk, ScD, Prof.,

Lviv Polytechnic National University, Department of Management Technologies, Lviv

Olha Kots, PhD, Ass. Prof.,

Lviv Polytechnic National University, Department of Finance, Lviv

Anastasiia Kud,

Lviv Polytechnic National University, Department of Finance, Lviv

\section{UKRAINIAN BANKING SYSTEM CAPITALIZATION INDICATORS: FACT STATE AND COMPARATIVE CHARACTERISTIC WITH POLAND, SWITZERLAND AND GERMANY}

Introduction. The development of both the banking sector of the country and the entire economy is dependent on the level of capitalization, because its insufficiency hinders economic development. That is why the study of capitalization, as well as finding ways to increase it, is relevant.

There are different indicators of determining the level of banking sector's capitalization, but the main one is the share of banks' capital in GDP. However, in practice, the dynamics and structure of banks' capital and the its usage efficiency are often analyzed.

The purpose of the article is to analyze the banking system capitalization, to make comparative characteristic with Poland, Switzerland and Germany, as well as to develop theoretical and applied recommendations on the formation of bank capital and increase the Ukrainian banking system capitalization.

Results. The level of Ukrainian banking system capitalization was determined on the basis of the share of banks' capital in GDP for 2000-2019. The decrease in the level of Ukrainian banking system capitalization by the analyzed indicator is caused by several factors: 1) excess of GDP growth rate over the growth rate of bank capital; 2) significant decrease in the number of banks in the banking system of Ukraine and, as a result, a decrease in banking capital. The main share in the banks' capital structure is the authorized capital, which is formed due to the owners' funds. Uncovered loss, which reaches more than 100\% from 2016 to 2019, has a negative impact on the amount of equity, that is, in the post-crisis period there is an accumulation of uncovered loss in the banking system of Ukraine. Despite the large number of banks in the Ukrainian banking system, 49.96\% (half) of the banking system's capital is accounted for by only 5 banks.

Considering the significant changes in the banking system of Ukraine that have come under the pressure of financial crises and as a result of the implementation of international standards of banking regulation, we consider it advisable to perform a comparative analysis of the capitalization of the banking systems of Ukraine, Poland, Switzerland and Germany. We can say that the National Bank of Ukraine should consider the experience of Germany in the reorganization and capitalization of the banking system, since 2012 they become similar in structural indicators. 
The experience of Poland was useful in the period 2010-2014, but in the current conditions banking systems of Ukraine and Poland are beginning to differ significantly.

Conclusions. The research results have showed a low level of Ukrainian banking system capitalization, revealed the prospects of applying the capitalization management experience of other countries in the Ukrainian economy. It is necessary additional capitalization of the Ukrainian banking system, because banking risks are significant, requiring increasing bank capital and requires a volume increase of banking activities in general and its role in the formation of Ukraine's GDP in particular.

Keywords: bank, capital, capitalization, banking system, valuation, comparison.

Постановка проблеми та їі значення. Недостатній рівень капіталізації банківської системи України є проблемою впродовж усіх років незалежності, проте саме в умовах глобалізації та міжнародної фінансової інтеграції воно набуває особливої актуальності. Розвиток як банківського сектору країни, так і всієї економіки є залежним від рівня капіталізації, адже їі недостатність стримує економічний розвиток. Саме тому дослідження капіталізації, а також знаходження шляхів піi підвищення є актуальним.

Капітал банку є одним із найважливіших показників надійності капіталовкладень для вкладника, адже капітал стає джерелом відшкодування збитків, якщо настане банкрутство банку. Поняття капіталу банку тісно пов'язане із такою економічною категорією як капіталізація. Частка статутного капіталу банківської системи України ніколи не перевищувала 35\%, в той же час в Свропі вона становить більше 40\%, а в США - 80\% [1]. Тому сьогодні $\epsilon$ необхідним збільшення рівня капіталізації банківської системи України, що допоможе банкам здійснювати ефективне фінансове посередництво на ринку банківських послуг.

Аналіз останніх досліджень і публікацій. Існують різні індикатори рівня капіталізації банківського сектора, проте основним можна назвати відношення сукупного банківського капіталу до ВВП. Його нормативне значення становить близько 6\%. Для того щоб відбулося збільшення рівня капіталізації потрібно, щоб капітал банківської системи зростав швидше, ніж ВВП в країні [2].

Сьогодні НБУ здійснює активну політику капіталізації банківської системи України. У 2018 р. було започатковано проведення щорічної оцінки стійкості банків та банківської системи України. Результатом оцінки є визначення суми нестачі в капіталі. Якщо в банку виявлено потребу в ньому, то він повинен забезпечувати покриття нестачі у капіталі шляхом виконання програми капіталізації та плану реструктуризації. Проте даною процедурою користується менше 20\% банків, які збільшують статутний капітал. У своїй практиці НБУ для оцінювання рівня капіталізації користується певними нормативами, а саме: Н1 як показник абсолютного рівня капіталізації (500 млн. грн.) та Н2 норматив достатності регулятивного капіталу як відносний визначник (не менше 10\%) [3, 4].

Капіталізацію банківської системи, достатність капіталу та способи підвищення обсягів капіталу і рівня капіталізації широко досліджують вчені-економісти. Сьогодні дослідженням капіталу банків та капіталізації банківської системи України займаються Р. V. Gudź, Р. В. Фірман [5, с. 241-247], 3. М. Васильченко, І. В. Доманецький [6, с. 3-10], Л. О. Вдовенко, О. С. Черненко [7, с. 85-96], О. В. Добровольська, С. М. Халатур [8], О. В. Лисенок [9, 10], О. В. Нєізвєстна, Г. О. Верич [11, с. 141144], Н. С. Островська, О. Ю. Швець [12, с. 145-150], Ю. О. Швець, М. Ю. Вернидуб [13, с. 52-57], А. М. Шевчук [14, 15] та інші.

Так, Є. М. Андрущак, О. І. Щуревич стверджують, що «капітал банку має бути адекватним обсягу здійснюваних банком активних операцій. Це означає, що елементи капіталу повинні бути якісними з точки зору можливостей поглинання ризиків» [3, с. 129]. І. Б. Дмитренко зазначає, що банки надають перевагу мінімальному обсягу капіталу, що дає змогу покращити показники рентабельності акціонерного капіталу і збільшити активи; а от НБУ вимагає більшого обсягу капіталу задля зменшення ризику неплатоспроможності банку [16, с. 121]. О. В. Лисенок запропоновано систему показників для оцінювання капіталізації банку, що включає як макро-, так i мікро-економічні показники [9, с. 262; 10].

Метод оцінювання капіталізації банку на основі комплексу моделей пропонують Ю. Ю. Гусєва та С. В. Байталюк [13, с. 75-83], які враховують такі показники: коефіцієнт капіталізації, коефіцієнт покриття зобов'язань, темп приросту капіталу. Також ці моделі передбачають розрахунок дохідності капіталу, мультиплікатора капіталу, дохідності активів, коефіцієнта співвідношення приростів 
капіталу та активів, фінансового левериджу та темпів приросту активів. Така методика $\epsilon$ багатосторонньою, враховує ключові показники діяльності банку, проте вимагає систематизації значного масиву даних та використання засобів моделювання для отримання результатів, що будуть придатними для використання при розробленні управлінських рішень.

Попри значні теоретичні дослідження капіталізації банків і банківської системи недостатньо уваги приділено практичним підходам до аналізування капіталізації банківської системи, не виявлено порівняльного аналізу рівнів капіталізації банківської системи України та інших країн, а також потребує удосконалення інструментарій оцінювання рівня капіталізації, задля чого потрібно грунтовно дослідити її рівень та ідентифікувати перспективи змін.

Мета і завдання статті. Метою статті $є$ аналізування капіталізації банківської системи України, порівняльна характеристика із показниками Польщі, Швейцарії та Німеччини, а також ідентифікація найбільш доцільних для імплементації закордонних практик організування банківської діяльності.

Викладення основного матеріалу та обгрунтування отриманих результатів дослідження. Проаналізуємо рівень капіталізації банківської системи України на основі частки капіталу банків у ВВП за 2010-2019 рр. (табл. 1).

Табличя 1

Рівень капіталізації банківської системи України на основі частки капіталу банків у ВВП за 2010-2019 pр. (дані за станом на 01.01)

\begin{tabular}{|c|c|c|c|c|c|c|c|c|c|c|}
\hline Роки & 2010 & 2011 & 2012 & 2013 & 2014 & 2015 & 2016 & 2017 & 2018 & 2019 \\
\hline $\begin{array}{c}\text { Капітал, млн. } \\
\text { грн. }\end{array}$ & 120208 & 137725 & 155487 & 170196 & 192599 & 148063 & 94914 & 116434 & 157364 & 154960 \\
\hline $\begin{array}{c}\text { Темп приросту } \\
\text { капіталу, \% }\end{array}$ & - & 14,57 & 12,9 & 9,46 & 13,16 & $-23,12$ & $-35,9$ & 22,67 & 35,15 & $-1,53$ \\
\hline ВВП, млн. грн. & 947042 & 1079346 & 1299991 & 1404669 & 1465198 & 1586915 & 1988544 & 2385367 & 2983882 & 3558706 \\
\hline $\begin{array}{c}\text { Темп приросту } \\
\text { ВВП, \% }\end{array}$ & - & 13,97 & 20,44 & 8,05 & 4,31 & 8,31 & 25,31 & 19,96 & 25,09 & 19,26 \\
\hline $\begin{array}{c}\text { Частка капіталу } \\
\text { у ВВП, \% }\end{array}$ & 12,69 & 12,76 & 11,96 & 12,12 & 13,14 & 9,33 & 4,77 & 4,88 & 5,27 & 4,35 \\
\hline
\end{tabular}

Джерело: сформовано авторами на основі даних [4]

Зниження рівня капіталізації банківської системи України за аналізованим показником із 12,69\% у 2010 р. до 4,35\% у 2019 р. зумовлено кількома чинниками: 1) перевищенням темпів зростання ВВП над темпами зростання капіталу банків; 2) значним зменшенням кількості банків у банківській системі України у період 2015-2019 рр., і як наслідок - зменшення банківського капіталу, обсяг якого не перевищує значень 2014 р., хоча й зростає впродовж 2016-2018 рр. Враховуючи зміни у банківський системі внаслідок фінансової кризи 2014-2015 pр., різких змін валютного курсу, що вплинули на значення ВВП, цей показник є малоінформативним при аналізуванні у динаміці доцільно здійснювати порівняння його значень у певні періоди із значеннями капіталізації банківської системи інших (еталонних або подібних) країн.

Табличяя 2

Структура капіталу банків України за 2010-2019 рр., \%

\begin{tabular}{|c|c|c|c|c|c|c|c|}
\hline Роки & $\begin{array}{c}\text { Статутний } \\
\text { капітал }\end{array}$ & $\begin{array}{c}\text { Емісійні } \\
\text { різниці }\end{array}$ & $\begin{array}{c}\text { Незареєстрований } \\
\text { статутний капітал }\end{array}$ & $\begin{array}{c}\text { Інший } \\
\text { додатковий } \\
\text { капітал }\end{array}$ & $\begin{array}{c}\text { Резервні та } \\
\text { iнші фонди } \\
\text { банку }\end{array}$ & $\begin{array}{c}\text { Резерви } \\
\text { пере- } \\
\text { оцінки }\end{array}$ & $\begin{array}{c}\text { Нерозподілений } \\
\text { прибуток } \\
\text { (непокритий } \\
\text { збиток) }\end{array}$ \\
\hline 2010 & 97,75 & 7,55 & 0,00 & 0,00 & 12,89 & 7,10 & $-25,28$ \\
\hline 2011 & 106,57 & 6,27 & 0,00 & 0,00 & 9,67 & 9,08 & $-31,58$ \\
\hline 2012 & 110,76 & 5,93 & 0,00 & 0,00 & 7,75 & 8,78 & $-33,23$ \\
\hline 2013 & 103,55 & 6,87 & 0,51 & 0,00 & 11,30 & 7,70 & $-29,93$ \\
\hline 2014 & 95,52 & 7,10 & 8,02 & 0,00 & 6,45 & 7,27 & $-24,36$ \\
\hline 2015 & 121,03 & 8,47 & 18,73 & 0,00 & 9,61 & 10,26 & $-68,11$ \\
\hline 2016 & 209,63 & 21,95 & 12,22 & 0,48 & 12,63 & 11,45 & $-168,35$ \\
\hline 2017 & 239,58 & 15,98 & 94,94 & 0,66 & 9,43 & $-4,28$ & $-256,31$ \\
\hline
\end{tabular}


РОЗДІЛ V. Гроші, фінанси та кредит. 1, 2020

\begin{tabular}{|c|c|c|c|c|c|c|c|}
\hline Роки & $\begin{array}{c}\text { Статутний } \\
\text { капітал }\end{array}$ & $\begin{array}{c}\text { Емісійні } \\
\text { різниці }\end{array}$ & $\begin{array}{c}\text { Незареєстрований } \\
\text { статутний капітал }\end{array}$ & $\begin{array}{c}\text { Інший } \\
\text { додатковий } \\
\text { капітал }\end{array}$ & $\begin{array}{c}\text { Резервні та } \\
\text { інші фонди } \\
\text { банку }\end{array}$ & $\begin{array}{c}\text { Резерви } \\
\text { пере- } \\
\text { оцінки }\end{array}$ & $\begin{array}{c}\text { Нерозподілений } \\
\text { прибуток } \\
\text { (непокритий } \\
\text { збиток) }\end{array}$ \\
\hline 2018 & 305,42 & 8,15 & 6,47 & 4,01 & 10,92 & 14,63 & $-249,58$ \\
\hline 2019 & 292,06 & 8,80 & 2,88 & 3,98 & 11,97 & 10,94 & $-230,63$ \\
\hline
\end{tabular}

Джерело: сформовано авторами на основі даних [4]

Темп приросту ВВП є досить нерівномірним. Найменший темп приросту був у 2014 р. (4,31 \%), а найбільший - в 2016 та в 2018 pp. (25,31 \% та 25,09 \% відповідно), проте якщо взяти до уваги в цих роках інфляцію, то зміна реального ВВП буде іншою. Темп приросту капіталу банків впродовж аналізованого періоду є також різним, що, в першу чергу, відображає стан фінансової сфери України у відповідні періоди (наявність криз, піднесення тощо), а також корелює із кількістю учасників банківської системи.

У табл. 2 наведено структуру капіталу банківської системи України за 2010-2019 pр.

Основну частку в структурі капіталу банків займає статутний капітал, який формується за рахунок коштів власників. Бачимо, що з 2016 р. він суттєво зростає (майже вдвічі). На це вплинула політика НБУ щодо збільшення норм власного капіталу банків (докапіталізація баків). Також вагому частку займає незареєстрований капітал, емісійні різниці та резерви. Негативний вплив на величину власного капіталу має непокритий збиток, який з 2016 р. до 2019 р. сягає більш ніж 100 \%, тобто у посткризовий період відбувається накопичення непокритого збитку у банківській системі України.

У табл. 3 наведено поділ банків за величиною капіталу. Метою даного оцінювання $\epsilon$ розмежування банків за величиною капіталу, адже чим більша величина капіталу, тим ефективніше і стабільніше функціонує банк. В свою чергу низький рівень капіталізації свідчить про малу надійність банку та його непривабливість для клієнтів.

Табличяя 3

Поділ банків за величиною власного капіталу за 2010-2019 рр.

\begin{tabular}{|c|c|c|c|c|c|c|c|c|c|}
\hline \multirow[t]{2}{*}{ Капітал } & \multicolumn{2}{|c|}{$\begin{array}{c}\text { Менше } 500 \\
\text { млн. грн }\end{array}$} & \multicolumn{2}{|c|}{$\begin{array}{c}500-1000 \text { млн. } \\
\text { грн. }\end{array}$} & \multicolumn{2}{|c|}{$\begin{array}{l}1000-5000 \\
\text { мЛн. грн. }\end{array}$} & \multicolumn{2}{|c|}{$\begin{array}{c}\text { Більше } 5000 \\
\text { млн. грн. }\end{array}$} & \multirow{2}{*}{$\begin{array}{l}\text { Кількість } \\
\text { банків, од. }\end{array}$} \\
\hline & од. & $\%$ & од. & $\%$ & од. & $\%$ & од. & $\%$ & \\
\hline 2010 & 138 & 77,09 & 16 & 8,94 & 19 & 10,61 & 6 & 3,35 & 179 \\
\hline 2011 & 129 & 73,71 & 22 & 12,57 & 19 & 10,86 & 5 & 2,86 & 175 \\
\hline 2012 & 128 & 73,14 & 19 & 10,86 & 22 & 12,57 & 6 & 3,43 & 175 \\
\hline 2013 & 125 & 71,43 & 19 & 10,86 & 25 & 14,29 & 6 & 3,43 & 175 \\
\hline 2014 & 130 & 72,22 & 21 & 11,67 & 22 & 12,22 & 7 & 3,89 & 180 \\
\hline 2015 & 113 & 71,52 & 20 & 12,66 & 18 & 11,39 & 7 & 4,43 & 158 \\
\hline 2016 & 80 & 73,39 & 12 & 11,01 & 13 & 11,93 & 4 & 3,67 & 109 \\
\hline 2017 & 57 & 61,29 & 15 & 16,13 & 15 & 16,13 & 6 & 6,45 & 93 \\
\hline 2018 & 48 & 57,14 & 13 & 15,48 & 14 & 16,67 & 9 & 10,71 & 84 \\
\hline 2019 & 41 & 53,25 & 14 & 18,18 & 12 & 15,58 & 10 & 12,99 & 77 \\
\hline
\end{tabular}

Джерело: сформовано та розраховано авторами на основі даних [4]

Хоча абсолютна кількість банків практично за усіма групами зменшувалася, проте у структурі банківської системи за критерієм обсягу капіталу відбулися певні зміни. Так, частка банків із обсягом капіталу понад 5000 млн. грн. зросла з 3,35\% у 2010 р. до 12,99\% у 2019 р., тобто збільшилася частка великих банків в банківській системі України. Значним було зменшення частки малих банків (із капіталом менше 500 млн. грн.) - із 77,09\% у 2010 р. до 53,35\% у 2019 р. Також мало місце зростання і проміжних груп банків за обсягом капіталу. У 2019 р. 15,58\% банків мали капітал 1000-5000 млн. грн., а 18,18\% - 500-1000 млн. грн. Такі зміни у банківській системі є позитивними та сприятимуть стабільному їі функціонуванню.

Розглянемо топ-5 банків України за часткою капіталу (табл. 4).

Не зважаючи на велику кількість банків в банківській системі України, з табл. 4 бачимо, що у 2019 p. 49,96\% (половина) капіталу банківської системи припадає лише на 5 банків. Найменше 
значення показника спостерігається на початку 2017 р., що пов'язане зі зменшенням загальної суми капіталу всієї банківської системи (збитковістю банківської діяльності) та окремих банків зокрема. Найбільше значення показника спостерігається у 2018 р., однією з причин чого є влиття коштів в банківську систему, а саме в АТ КБ «ПРИВАТБАНК», частка капіталу якого у 2019 р. становить $22,32 \%$ (для порівняння - у 2010 р. 8,54\%, у 2017 р. - 10,24\%), тобто практично чверть капіталу банківської системи України зосереджено в АТ КБ «ПРИВАТБАНК». Кожен банк із топ-5 за обсягом капіталу збільшував частку капіталу у банківській системі України впродовж аналізованого періоду, тобто має місце концентрація банківського капіталу.

Таблиия 4

Топ-5 банків України за часткою капіталу, за 2010-2019 рр.\%

\begin{tabular}{|c|c|c|c|c|c|c|c|c|c|c|}
\hline Банки Роки & 2010 & 2011 & 2012 & 2013 & 2014 & 2015 & 2016 & 2017 & 2018 & 2019 \\
\hline $\begin{array}{c}\text { АТ КБ } \\
\text { «РИВАТБАНК» }\end{array}$ & 8,54 & 8,63 & 10,77 & 10,75 & 10,55 & 15,33 & 29,34 & 10,24 & 16,02 & 22,32 \\
\hline АТ «Ощадбанк» & 13,63 & 12,07 & 11,35 & 10,65 & 10,62 & 15,36 & 7,84 & 12,07 & 19,75 & 10,91 \\
\hline $\begin{array}{c}\text { АТ «Райффайзен Банк } \\
\text { Аваль» }\end{array}$ & 4,42 & 4,68 & 4,16 & 3,73 & 3,76 & 4,15 & 6,69 & 0,88 & 6,82 & 7,27 \\
\hline АТ «Укрексімбанк» & 9,04 & 12,67 & 11,40 & 10,49 & 9,39 & 9,14 & $-3,34$ & 4,25 & 9,04 & 5,24 \\
\hline АТ «УКРСИББАНК» & 4,08 & 3,53 & 0,81 & 1,54 & 1,38 & 1,20 & 1,92 & 0,91 & 3,49 & 4,22 \\
\hline Разом & 39,72 & 41,57 & 38,49 & 37,16 & 35,69 & 45,19 & 42,46 & 28,36 & 55,13 & 49,96 \\
\hline
\end{tabular}

Джерело: сформовано та розраховано авторами на основі даних [4]

Враховуючи значні зміни у банківській системі України, що відбулися під тиском фінансових криз та внаслідок імплементації міжнародних стандартів регулювання банківської діяльності, вважаємо за доцільне виконати порівняльне аналізування капіталізації банківських систем України, Польщі, Швейцарії та Німеччини (табл. 5)

Табличя 5

Темп приросту капіталу, активів та зобов'язань банків України, Польщі, Швейцарії та Німеччини за 2011-2019 рр.

\begin{tabular}{|c|c|c|c|c|c|c|c|c|c|c|}
\hline \multirow{2}{*}{ Країни } & \multirow{2}{*}{ Показники } & \multicolumn{9}{|c|}{ Темп приросту, \% } \\
\hline & & 2011 & 2012 & 2013 & 2014 & 2015 & 2016 & 2017 & 2018 & 2019 \\
\hline \multirow{3}{*}{ Україна } & Капітал & 14,57 & 12,9 & 9,46 & 13,16 & $-23,12$ & $-35,9$ & 22,67 & 35,15 & $-1,53$ \\
\hline & Активи & 7,86 & 11,91 & 6,92 & 13,34 & 3,07 & $-7,32$ & 1,85 & 50,95 & 1,84 \\
\hline & Зобов'язання & 6,79 & 11,74 & 6,48 & 13,37 & 7,72 & $-3,59$ & $-0,67$ & 6,38 & 1,19 \\
\hline \multirow{3}{*}{ Польща } & Капітал & 12,75 & 27,48 & $-3,89$ & $-5,51$ & 16,98 & 6,63 & 5,89 & $-10,16$ & 10,72 \\
\hline & Активи & 9,35 & 12,03 & 2,69 & 3,89 & 9,65 & 4,79 & 13,99 & $-0,38$ & 8,12 \\
\hline & Зобов'язання & 9,85 & 14,37 & 1,58 & 2,39 & 10,73 & 5,07 & 12,71 & $-1,83$ & 8,48 \\
\hline \multirow{3}{*}{ Швейцарія } & Капітал & 0,21 & 0,48 & $-1,54$ & 6,45 & $-5,33$ & 4,69 & 2,49 & $-4,17$ & 1,83 \\
\hline & Активи & 1,74 & 2,89 & $-0,53$ & 2,55 & 6,76 & $-0,51$ & 2,49 & 4,77 & $-0,75$ \\
\hline & Зобов'язання & 1,75 & 2,91 & $-0,52$ & 2,51 & 6,88 & 0,36 & 1,55 & 4,86 & $-0,77$ \\
\hline \multirow{3}{*}{ Німеччина } & Капітал & $-0,48$ & 3,42 & 4,1 & 3,22 & 6,44 & 6,33 & 3,9 & 15,98 & 1,4 \\
\hline & Активи & 11,68 & 1,07 & $-1,99$ & $-8,48$ & 3,63 & $-1,76$ & 1,66 & $-1,05$ & 0,85 \\
\hline & Зобов'язання & 12,47 & 0,93 & $-2,35$ & $-9,22$ & 3,43 & $-2,35$ & 1,48 & $-2,45$ & 0,79 \\
\hline
\end{tabular}

Джерело: розраховано авторами на основі даних $[4,18,19,20]$

Середньорічний темп приросту капіталу банків в Україні становить 2,86\%, активів - 9,09\%, а зобов'язань - 5,36\%, тобто темпи приросту капіталу є меншими за темпи приросту активів та зобов'язань. Найбільше зростання активів банківської системи України спостерігається у 2018 р. (на $50,95 \%$ ), що пов'язано із зростання кредитних портфелів банків, які в загальній сумі активів становлять близько $30 \%$. Вплив фінансової кризи бачимо по від'ємних значеннях темпів приросту аналізованих показників банківської системи України.

Середньорічний темп приросту капіталу банків в Польщі становить $6,18 \%$, активів $-7,04 \%$, а зобов'язань $-6,91 \%$. Аналогічно, як і в Україні, темп приросту капіталу є нижчим, ніж темпи 
приросту активів та зобов'язань, проте вони є вищими в Польщі, ніж в Україні. Кризові періоди в Польщі не співпадають із кризами в Україні, що свідчить про внутрішній характер фінансових явищ та процесів.

Здійснивши аналізування темпів приросту капіталу, активів та зобов'язань банків Швейцарії за 2011-2019 pр., бачимо, що вони є нижчими, ніж в інших аналізованих країнах. Середньорічний темп приросту капіталу банків Швейцарії становить $0,5 \%$, активів $-2,13 \%$, а зобов'язань $-2,14 \%$. Активи i зобов'язання зростають майже однаковими темпами впродовж усього аналізованого періоду, а капітал - значно повільнішими. Високо розвинута банківська система Швейцарії у аналізованому періоді практично не змінювалася - не піддавалася кризам та не реагувала на зміну кон'юнктури фінансового ринку на відміну від банківських систем України та Польщі.

Середньорічний темп приросту капіталу банків в Німеччини становить $4,83 \%$, активів $-0,5 \%$, а зобов'язань - 0,16\%. Тобто зі всіх аналізованих країн лише в Німеччині капітал банків зростає набагато швидшими темпами, ніж активи та зобов'язання. Щодо капіталу, то він зростав найшвидшими темпами в 2018 р. (на 15,98\% порівняно із 2017 р.). Найсуттєвіше зменшення відбулося в 2011 р. (-0,48\%). Найбільше зростання активів спостерігається у 2011 р. (на 11,68\%). Найбільший приріст зобов'язань спостерігається теж в 2011 р. (на 12,47\%). Фактично 2011 р. для Німеччини є одним із ключових періодів відновлення банківської системи після негативного впливу світової фінансової кризи.

Порівняємо також структурні показники - частку капіталу в активах, зобов'язаннях та коштах клієнтів для банків України, Польщі, Швейцарії та Німеччини за 2010-2019 рр. (табл. 6).

Частка капіталу в активах, зобов'язаннях та коштах кліснтів для банків України, Польші, Швейцарії та Німеччини за 2010-2019 рр.

\begin{tabular}{|c|c|c|c|c|c|c|c|c|c|c|c|c|}
\hline \multirow{2}{*}{ Роки } & \multicolumn{4}{|c|}{ Частка капіталу в активах,\% } & \multicolumn{4}{|c|}{$\begin{array}{c}\text { Частка капіталу в коштах } \\
\text { клієнтів, \% }\end{array}$} & \multicolumn{4}{|c|}{$\begin{array}{l}\text { Частка капіталу в } \\
\text { зобов'язаннях, \% }\end{array}$} \\
\hline & $\begin{array}{l}\text { Укра- } \\
\text { їна }\end{array}$ & $\begin{array}{c}\text { Поль- } \\
\text { ща }\end{array}$ & $\begin{array}{l}\text { Швей- } \\
\text { царія }\end{array}$ & $\begin{array}{c}\text { Німеч- } \\
\text { чина }\end{array}$ & $\begin{array}{l}\text { Укра- } \\
\text { їна }\end{array}$ & $\begin{array}{l}\text { Поль- } \\
\text { ща }\end{array}$ & $\begin{array}{l}\text { Швей- } \\
\text { царія }\end{array}$ & $\begin{array}{c}\text { Німеч- } \\
\text { чина }\end{array}$ & $\begin{array}{c}\text { Укра- } \\
\text { їна } \\
\end{array}$ & $\begin{array}{c}\text { Поль- } \\
\text { ща }\end{array}$ & $\begin{array}{l}\text { Швей- } \\
\text { царія }\end{array}$ & $\begin{array}{c}\text { Нiмеч- } \\
\text { чина }\end{array}$ \\
\hline 2010 & 13,76 & 14,70 & 0,99 & 6,12 & 25,43 & 28,30 & 1,89 & 16,14 & 15,96 & \begin{tabular}{|l|l}
17,30 \\
\end{tabular} & 1,00 & 6,51 \\
\hline 2011 & 14,62 & 15,10 & 0,98 & 5 & 23,03 & 29,20 & 1,91 & 15,47 & 17,12 & 17,80 & 0,99 & 5,76 \\
\hline 2012 & 14,75 & 16,9 & 0,96 & 5,58 & 21,83 & 33,2 & 1,82 & 15,43 & 17,3 & 20,3 & 0,96 & 5,91 \\
\hline 2013 & 15,1 & 15,9 & 0,95 & 5,92 & 28,48 & 30,3 & 1,70 & 15,76 & 17,78 & 19 & 0,95 & 6,3 \\
\hline 2014 & 15,08 & 14,7 & 0,98 & 6,68 & 27,4 & 26,9 & 1,67 & 16,07 & 17,75 & 17,3 & 0,99 & 7,16 \\
\hline 2015 & 11,24 & 15,5 & 0,87 & 6,86 & 20,62 & 29,1 & 1,50 & 16,74 & 12,67 & 18,4 & 0,88 & 7,37 \\
\hline 2016 & 7,68 & 15,8 & 0,00 & 7,43 & 12,51 & 28,7 & 0,00 & 17,21 & 8,31 & 18,7 & 0,00 & 8,02 \\
\hline 2017 & 9,95 & 14,8 & 0,92 & 7,59 & 14,55 & 27,9 & 1,60 & 17,34 & 11,05 & 17,4 & 0,92 & 8,21 \\
\hline 2018 & 8,52 & 13,6 & 0,84 & 8,9 & 17,19 & 24,1 & 1,52 & 19,44 & 13,43 & 15,7 & 0,84 & 9,77 \\
\hline 2019 & 8,44 & 13,8 & 0,86 & 8,95 & 17,53 & 24,5 & 1,53 & 19,1 & 14,28 & 16,1 & 0,87 & 9,82 \\
\hline
\end{tabular}

Джерело: сформовано та розраховано авторами на основі даних $[4,18,19,20]$

Частка капіталу в активах $є$ найвищою в Польщі, а найнижчою - у Швейцарії, що зумовлено високими ризиками ведення банківської діяльності, що потребують збільшеного фінансування за рахунок капіталу (і зменшеного - за рахунок зобов'язань) у порівнянні з країнами зі стійкими та розвинутими банківськими системами. Україна $є$ близькою за значеннями цього показника до Польщі у період 2010-2014 pр., та до Німеччини у період 2015-2019 pp. Тобто внаслідок кризи 20142015 рр. в Україні відбувається не лише реорганізація банківської системи, але й зміна структури капіталу банків. Частка капіталу в коштах клієнтів за 2010-2019 рр. зростала лише в Німеччині. Найбільшою у 2019 р. вона була в Польщі, а найнижчою - в Швейцарії. Аналогічною є ситуація і 3 часткою капіталу у зобов'язаннях. Тобто можемо стверджувати, що НБУ доцільно враховувати досвід Німеччини при реорганізації та капіталізації банківської системи України, адже починаючи 3 2012 р. вони стають схожими за структурними показниками, а от досвід Польщі був корисним у період 2010-2014 рр., проте в сучасних умовах банківські системи України та Польщі починають суттєво відрізнятися. 
Результати розрахунку ефективності використання (рентабельності) капіталу та активів для банків України, Польщі, Швейцарії та Німеччини за 2010-2019 рр. наведено в табл. 7.

Висока волатильність рентабельності капіталу та активів банків України, перш за все, зумовлена впливом фінансових криз, невмінням зменшувати їхні негативні наслідки, проактивно реагувати на зміни господарської кон'юнктури тощо. Динамічність фінансової сфери вимагає цих вмінь та навиків, адже адаптивність не дає змоги ефективно вести банківську діяльність в сучасних мінливих ринкових умовах. Висока рентабельність капіталу у Швейцарії та стабільна рентабельність капіталу Польщі є ознаками проактивного банківського бізнесу в цих країнах, адже рентабельність активів у цих же країнах має стабільні додатні значення. Банківська система Німеччини функціонує в межах нульової ефективності по активах та практично нульової ефективності по капіталу, незначні коливання в яких то перевищують 0 , то $є$ нижчими 0 (тобто характеризують збитковість банківської діяльності в Німеччині).

Таблиия 7

Результати розрахунку рентабельності капіталу та активів для банків України, Польщі, Швейцарії та Німеччини за 2010-2019 рр.

\begin{tabular}{|c|c|c|c|c|c|c|c|c|}
\hline \multirow{2}{*}{ Роки } & \multicolumn{3}{|c|}{ Рентабельність капіталу, \% } & \multicolumn{4}{c|}{ Рентабельність активів, \% } \\
\cline { 2 - 9 } & Україна & Польща & Швейцарія & Німеччина & Україна & Польща & Швейцарія & Німеччина \\
\hline 2010 & $-26,20$ & 5,88 & 9,02 & $-1,03$ & $-3,61$ & 0,87 & 0,09 & $-0,06$ \\
\hline 2011 & $-9,46$ & 5,64 & 40,08 & $-0,15$ & $-1,38$ & 0,85 & 0,39 & $-0,01$ \\
\hline 2012 & $-4,96$ & 6,01 & 48,73 & $-0,17$ & $-0,73$ & 1,01 & 0,47 & $-0,01$ \\
\hline 2013 & 2,88 & 6,24 & 0,71 & $-0,04$ & 0,43 & 0,99 & 0,01 & 0,00 \\
\hline 2014 & 0,75 & 6,43 & 37,63 & $-0,33$ & 0,11 & 0,95 & 0,37 & $-0,02$ \\
\hline 2015 & $-35,44$ & 5,76 & 27,85 & 0,36 & $-3,99$ & 0,90 & 0,24 & 0,02 \\
\hline 2016 & $-75,74$ & 4,35 & 56,99 & 0,47 & $-5,89$ & 0,69 & 0,52 & 0,04 \\
\hline 2017 & $-136,11$ & 4,46 & 27,86 & 0,76 & $-12,75$ & 0,66 & 0,26 & 0,06 \\
\hline 2018 & $-16,50$ & 4,89 & 35,90 & 0,47 & $-1,38$ & 0,66 & 0,30 & 0,04 \\
\hline 2019 & 5,96 & 4,22 & 41,55 & $-0,14$ & 0,46 & 0,58 & 0,36 & $-0,01$ \\
\hline
\end{tabular}

Джерело: розраховано авторами на основі даних $[4,18,19,20]$

Можемо стверджувати, що для банківської системи України першочерговим завданням $є$ стабілізація фінансових результатів, для чого доцільно скористатися досвідом Німеччини, а от для подальшого розвитку та закріплення отриманих результатів можна буде впроваджувати досвід країн із прибутковими банківськими системами. Сьогодні ж значні коливання у показниках банківської діяльності не дають змоги забезпечити фінансову стабільність ні в банківській системі, ні в країні в цілому.

На заключному етапі порівняльного аналізування банківських систем України, Польщі, Швейцарії та Німеччини виконаємо розрахунок та порівняння коефіцієнтів фінансової незалежності та капіталізації за 2010-2019 pр. (табл. 8).

\section{Результати розрахунку коефіцієнтів фінансової незалежності та капіталізації банківських} систем України, Польщі, Швейцарії та Німеччини за 2010-2019 рр.

\begin{tabular}{|c|c|c|c|c|c|c|c|c|}
\hline \multirow{2}{*}{ Роки } & \multicolumn{3}{|c|}{ Коефіціснт фінансової незалежності, \% } & \multicolumn{4}{c|}{ Коефіцієнт капіталізації, \% } \\
\cline { 2 - 9 } & Укаїна & Польща & Швейцарія & Німеччина & Україна & Польща & Швейцарія & Німеччина \\
\hline 2010 & 15,96 & 17,28 & 1,00 & 6,51 & 12,69 & 13,66 & 4,02 & 12,13 \\
\hline 2011 & 17,12 & 17,82 & 0,99 & 5,76 & 12,76 & 14,15 & 4,55 & 12,09 \\
\hline 2012 & 17,30 & 20,27 & 0,96 & 5,91 & 11,96 & 16,35 & 3,81 & 11,35 \\
\hline 2013 & 17,78 & 18,98 & 0,95 & 6,30 & 12,12 & 16,59 & 3,93 & 12,55 \\
\hline 2014 & 17,75 & 17,26 & 0,99 & 7,16 & 13,14 & 14,97 & 4,06 & 12,25 \\
\hline 2015 & 12,67 & 18,41 & 0,88 & 7,37 & 9,33 & 16,84 & 3,73 & 12,51 \\
\hline 2016 & 8,42 & 18,73 & 0,92 & 8,02 & 4,77 & 20,50 & 4,08 & 15,39 \\
\hline 2017 & 10,40 & 17,40 & 0,92 & 8,21 & 4,88 & 21,97 & 4,23 & 15,50 \\
\hline 2018 & 13,22 & 15,69 & 0,84 & 9,77 & 5,27 & 17,68 & 4,00 & 17,02 \\
\hline
\end{tabular}




\begin{tabular}{|c|c|c|c|c|c|c|c|c|}
\hline \multirow{2}{*}{ Роки } & \multicolumn{3}{|c|}{ Коефіціснт фінансової незалежності, \% } & \multicolumn{4}{c|}{ Коефіцієнт капіталізації, \% } \\
\cline { 2 - 8 } & Україна & Польща & Швейцарія & Німеччина & Україна & Польща & Швейцарія & Німеччина \\
\hline 2019 & 12,29 & 16,07 & 0,87 & 9,82 & 4,35 & 17,60 & 3,93 & 16,00 \\
\hline
\end{tabular}

Джерело: розраховано авторами на основі даних $[4,18,19,20]$

Коефіцієнт фінансової незалежності банківської системи України впродовж аналізованого періоду постійно змінюється як в позитивному, так і в негативному напрямі . Середнє значення показника становить 14,29\% - це означає, що капітал покриває 14,29\% активів. Щодо коефіцієнта фінансової незалежності банківської системи Польщі, то тут ситуація дещо краща, ніж в Україні. Середнє значення становить $17,80 \%$, тобто капітал покриває $17,80 \%$ активів. Динаміка коефіцієнта фінансової незалежності банківської системи Швейцарії значно відрізняється від інших країн - його середнє значення становить $0,93 \%$. Коефіцієнт фінансової незалежності банківської системи Німеччини впродовж аналізованого періоду $є$ значно меншим, ніж в Україні і Польщі, проте більший, ніж у Швейцарії, а його середнє значення дорівнює 7,48\%.

Порівнюючи значення коефіцієнта фінансової автономії та капіталізації для чотирьох аналізованих країн, бачимо, що для Швейцарії характерний низький рівень капіталізації (близько 4\%), а от для Німеччини та Польщі - доволі високий - 16-17\% у 2019 р. Загальною тенденцією $є$ зростання капіталізації банківської системи Польщі та Німеччини впродовж аналізованого періоду та стабільність капіталізації банківської системи Швейцарії. В Україні ж мало місце зниження капіталізації банківської системи із максимальних 13,14\% у 2014 р. до поточних 4,35\% (у 2019 р.).

Така ситуація є аномальною та потребує зміни, тобто необхідною $є$ докапіталізація банківської системи України, адже ризики банківської діяльності є значними, що потребує нарощення капіталу банками, а також необхідним є нарощення обсягів банківської діяльності загалом та іiі ролі у формуванні ВВП України.

Висновки і перспективи подальших досліджень. У дослідженні детальну увагу було приділено оцінюванню капіталізації банківської системи України, а також порівняльному аналізуванню капіталізації банківських систем України, Польщі, Швейцарії та Німеччини. Можемо стверджувати, що НБУ доцільно враховувати досвід Німеччини при реорганізації та капіталізації банківської системи України, адже починаючи з 2012 р. вони стають схожими за структурними показниками, а от досвід Польщі був корисним у період 2010-2014 pp., проте в сучасних умовах банківські системи України та Польщі починають суттєво відрізнятися. Для банківської системи України першочерговим завданням $є$ стабілізація фінансових результатів, для чого доцільно скористатися досвідом Німеччини, а от для подальшого розвитку та закріплення отриманих результатів можна буде впроваджувати досвід країн із прибутковими банківськими системами. Виконане дослідження показало низький рівень капіталізації банківської системи України, дало змогу виявити перспективи застосування досвіду управління капіталізацією банківської системи інших країн в умовах української економіки.

У подальших дослідженнях основну увагу доцільно зосередити на розробленні моделей управління капіталізацією банківської системи України.

\section{Джерела та література}

1. Грудзевич Я. В., Грудзевич У. Я. Капіталізація банківської системи України на сучасному етапі. Вісник Університету банківської справи. 2016. №1-2. C. 24-29. URL: http://nbuv.gov.ua/UJRN/VUbsNbU_2016_1-2_6.

2. Блащук-Дев'яткіна Н. З., Петик Л. О. Капіталізація банківської системи України. Економіка. Фінанси. Право. 2017. №4(1). С. 12-15. URL: http://nbuv.gov.ua/UJRN/ecfipr_2017_4(1)_5.

3. Андрущак С. М., Щуревич О. І. Проблеми капіталізації банківської системи України. Стратегія економічного розвитку України. 2018. № 42. C. 128-138. URL: http://nbuv.gov.ua/UJRN/seru_2018_42_14.

4. Офіційний сайт Національного банку України. URL: http://www.bank.gov.ua (дата звернення : 26.12.2019).

5. Gudź P. V., Фірман Р. В. Аналіз капіталізації комерційних банків України та шляхи іï нарощення. Економічний форум. 2014. №3. C. 241-247. URL: http://nbuv.gov.ua/UJRN/ecfor_2014_3_38. 
6. Васильченко 3. М., Доманецький I. В. Капіталізація банків України: сучасний стан та проблеми нарощення. Фінансово-кредитна діяльність: проблеми теорї та практики. 2013. Випуск 1 (14). C. 3-10. URL: http://nbuv.gov.ua/UJRN/Fkd_2013_1_3.

7. Вдовенко Л. О., Черненко О. С. Високий рівень капіталізації - основа зміцнення банківської системи України. Економіка. Фінанси. Менеджмент: актуальні питання науки і практики. 2017. № 4. C. 84-96. URL: http://nbuv.gov.ua/UJRN/efmapnp_2017_4_10.

8. Добровольська О. В., Халатур С. М. Капіталізація банків України в умовах глобалізації фінансових ринків. Вісник Дніпропетровського державного аграрного університету. 2011. №2. URL: http://nbuv.gov.ua/UJRN/vddau_2011_2_48 (дата звернення : 26.12.2019).

9. Лисенок О. В. Капіталізація вітчизняних банків та іiі вплив на валовий внутрішній. Вісник Житомирського державного технологічного університету. Сер. : Економічні науки. 2013. №2. С. 261-266. URL: http://nbuv.gov.ua/UJRN/Vzhdtu_econ_2013_2_34.

10. Лисенок О. В., Ляховецька В. М. Сучасний стан та шляхи підвищення рівня капіталізації вітчизняних банків. Науковий вісник Херсонського державного університету. Сер. : Економічні науки. 2017. Вип. 27(3). С. 55-58. URL: http://nbuv.gov.ua/UJRN/Nvkhdu_en_2017_27(3)__14.

11. Нєізвєстна О. В., Верич Г. О. Проблеми капіталізації банківської системи України та рекомендації щодо їх вирішення. Науковий вісник Міжнародного гуманітарного університету. Серія : Економіка $i$ менеджмент. 2016. Вип. 22. С. 141-144. URL: http://nbuv.gov.ua/UJRN/Nvmgu_eim_2016_22_33.

12. Островська Н. С., Швець О. Ю. Капіталізація банківської системи: сучасний стан та перспективи у трансформаційних умовах розвитку економіки України. Причорноморські економічні студіï. 2017. Вип. 21. С. 145-150. URL: http://nbuv.gov.ua/UJRN/bses_2017_21_30.

13. Швець Ю. О., Вернидуб М. Ю. Проблеми та способи підвищення капіталізації банків України. Інвестииї̈: практика та досвід. 2016. № 8. C. 52-57. URL: http://nbuv.gov.ua/UJRN/ipd_2016_8_13.

14. Шевчук А. М. Аналіз капіталізації банківської системи України. Наукові записки Національного університету «Острозька академія». Серія : Економіка. 2017. Вип. 4. C. 186-192. URL: http://nbuv.gov.ua/UJRN/Nznuoa_2017_4_37.

15.Шевчук А. Підвищення капіталізації банківської системи України шляхом макропруденційного регулювання Національного банку України. Науковий вісник Одеського національного економічного університету. 2018. № 8. С. 190-211. URL: http://nbuv.gov.ua/UJRN/Nv_2018_8_16.

16. Дмитренко I. Б. Сучасні підходи до оцінки достатності (адекватності) капіталу банків в Україні. Вчені записки Таврійського наџіонального університету імені В. І. Вернадського. Серія : Економіка і управління. 2019. T. 30(69). №4(1). C. 120-127. URL: http://nbuv.gov.ua/UJRN/UZTNU_econ_2019_30(69)_4(1)_23.

17. Гусєва Ю. Ю., Байталюк С. В. Діагностика рівня капіталізації банківської установи. Економіка та управління підприсмствами машинобудівної галузі. $2012 . \quad$ №2. http://nbuv.gov.ua/UJRN/eupmg_2012_2_8.

18. Офіційний сайт Національного банку Польщі. URL: http://www.nbp.pl (дата звернення : 26.12.2019).

19. Офіційний сайт Національного банку Швейцарії. URL: http://www.snb.ch (дата звернення : 26.12.2019).

20. Офіційний сайт Федерального банку Німеччини. URL: http://www.bundesbank.de (дата звернення : 26.12.2019).

\section{References}

1. Hrudzevych Ya. V., Hrudzevych U. Ya. (2016) Kapitalizatsiia bankivskoi systemy Ukrainy na suchasnomu etapi [Capitalization of the banking system of Ukraine at the present stage]. Visnyk Universytetu bankivskoi spravy Bulletin of the Banking University, 1-2, 24-29 [In Ukrainian].

2. Blashchuk-Deviatkina N. Z., Petyk L. O. (2017) Kapitalizatsiia bankivskoi systemy Ukrainy [Capitalization of the banking system of Ukraine]. Ekonomika. Finansy. Pravo-Economic. Finance. Law, 4(1), 12-15 [In Ukrainian].

3. Andrushchak Ye. M., Shchurevych O. I. (2018) Problemy kapitalizatsii bankivskoi systemy Ukrainy [Problems of capitalization of the banking system of Ukraine]. Stratehiia ekonomichnoho rozvytku Ukrainy - Strategy of economic development of Ukraine, 42, 128-138 [In Ukrainian].

4. Ofitsiinyi sait Natsionalnoho banku Ukrainy [Official site of the National Bank of Ukraine]. Retrieved from: http://www.bank.gov.ua.

5. Gudź P. V., Firman R. V. (2014) Analiz kapitalizatsii komertsiinykh bankiv Ukrainy ta shliakhy yii naroshchennia [Analysis of the capitalization of commercial banks of Ukraine and ways to increase it]. Ekonomichnyi forum - Economic Forum, 3, 241-247 [In Ukrainian].

6. Vasylchenko Z. M., Domanetskyi I. V. (2013) Kapitalizatsiia bankiv Ukrainy: suchasnyi stan ta problemy naroshchennia [Capitalization of Ukrainian banks: current state and problems of growth]. Finansovo-kredytna 
diialnist: problemy teorii ta praktyky - Financial and credit activity: problems of theory and practice, 1(14), 3-10 [In Ukrainian].

7. Vdovenko L. O., Chernenko O. S. (2017) Vysokyi riven kapitalizatsii - osnova zmitsnennia bankivskoi systemy Ukrainy [High level of capitalization - the basis of strengthening the banking system of Ukraine]. Ekonomika. Finansy. Menedzhment: aktualni pytannia nauky i praktyky - Economy. Finance. Management: actual issues of science and practice, 4, 84-96 [In Ukrainian].

8. Dobrovolska O. V., Khalatur S. M. (2016) Kapitalizatsiia bankiv Ukrainy v umovakh hlobalizatsii finansovykh rynkiv [Capitalization of Ukrainian banks in the conditions of globalization of financial markets].Visnyk Dnipropetrovskoho derzhavnoho ahrarnoho universytetu - Bulletin of the Dnipropetrovsk State Agrarian University. Retrieved from: http://nbuv.gov.ua/UJRN/vddau_2016_2_48 [In Ukrainian].

9. Lysenok O. V. (2013) Kapitalizatsiia vitchyznianykh bankiv ta yii vplyv na valovyi vnutrishnii produkt [Capitalization of domestic banks and their impact on gross domestic product]. Visnyk Zhytomyrskoho derzhavnoho tekhnolohichnoho universytetu. Ser. : Ekonomichni nauky - Bulletin of the Zhytomyr State Technological University. Avg. : Economic Sciences, 2, 261-266 [In Ukrainian].

10. Lysenok O. V., Liakhovetska V. M. (2017) Suchasnyi stan ta shliakhy pidvyshchennia rivnia kapitalizatsii vitchyznianykh bankiv [The current state and ways of increasing the level of capitalization of domestic banks]. Naukovyi visnyk Khersonskoho derzhavnoho universytetu. Ser. : Ekonomichni nauky - Scientific Bulletin of the Kherson State University. Avg. : Economic Sciences, 27(3), 55-58 [In Ukrainian].

11. Nieizviestna O. V., Verych H. O. (2016) Problemy kapitalizatsii bankivskoi systemy Ukrainy ta rekomendatsii shchodo yikh vyrishennia [The problems of capitalization of the banking system of Ukraine and recommendations for their solution]. Naukovyi visnyk Mizhnarodnoho humanitarnoho universytetu. Seriia : Ekonomika i menedzhmentScientific Bulletin of the International Humanities University. Series: Economics and Management, 22, 141-144 [In Ukrainian].

12. Ostrovska N. S., Shvets O. Yu. (2017) Kapitalizatsiia bankivskoi systemy: suchasnyi stan ta perspektyvy u transformatsiinykh umovakh rozvytku ekonomiky Ukrainy [Capitalization of the banking system: the current state and prospects in the transformational conditions of economic development of Ukraine]. Prychornomorski ekonomichni studii-Black Sea Economic Studies, 21, 145-150 [In Ukrainian].

13. Shvets Yu. O., Vernydub M. Yu. (2016) Problemy ta sposoby pidvyshchennia kapitalizatsii bankiv Ukrainy [Problems and ways of raising the capitalization of Ukrainian banks]. Investytsii: praktyka ta dosvid - Investments: practice and experience, 8, 52-57 [In Ukrainian].

14. Shevchuk A. M. (2017) Analiz kapitalizatsii bankivskoi systemy Ukrainy [Analysis of capitalization of the banking system of Ukraine]. Naukovi zapysky Natsionalnoho universytetu «Ostrozka akademiia». Seriia : EkonomikaScientific Notes of the National University "Ostroh Academy”. Series: Economics, 4, 186-192 [In Ukrainian].

15. Shevchuk A. (2018) Pidvyshchennia kapitalizatsii bankivskoi systemy ukrainy shliakhom makroprudentsiinoho rehuliuvannia natsionalnoho banku Ukrainy [Increasing the capitalization of the Ukrainian banking system by macroprudential regulation of the National Bank of Ukraine]. Naukovyi visnyk Odeskoho natsionalnoho ekonomichnoho universytetu - Scientific Bulletin of the Odessa National Economic University, 8, 190211 [In Ukrainian].

16. Dmytrenko I. B. (2019) Suchasni pidkhody do otsinky dostatnosti (adekvatnosti) kapitalu bankiv v Ukraini [Modern approaches to the assessment of capital adequacy (adequacy) of banks in Ukraine]. Vcheni zapysky Tavriiskoho natsionalnoho universytetu imeni V. I. Vernadskoho. Seriia : Ekonomika i upravlinnia - Scientific notes of Taurida Vernadsky National University. Series: Economics and Management, 30(69), 4(1), 120-127 [In Ukrainian].

17. Husieva Yu. Yu., Baitaliuk S. V. (2012) Diahnostyka rivnia kapitalizatsii bankivskoi ustanovy [Diagnosis of the level of capitalization of a banking institution]. Ekonomika ta upravlinnia pidpryiemstvamy mashynobudivnoi haluzi - Economics and management of enterprises of machine-building industry, 2, 75-83 [In Ukrainian].

18. Ofitsiinyi sait Natsionalnoho banku Polshchi [Official Website of the National Bank of Poland]. Retrieved from: http://www.nbp.pl.

19. Ofitsiinyi sait Natsionalnoho banku Shveitsarii [Official Website of the National Bank of Switzerland].Retrieved from: http://www.snb.ch.

20. Ofitsiinyi sait Federalnoho banku Nimechchyny [Official Website of the Federal Bank of Germany]. Retrieved from: http://www.bundesbank.de. 